Only the dead have seen the end of the war ${ }^{\mathrm{i}}$ - How to make sense of Turkey's involvement in Syria ${ }^{1}$

Sebastian Franzkowiak*

On August 24 2016, Turkey launched its military operation Euphrates Shield, crossing the Syrian border to take hold of Jarablus, the Islamic State's last direct access point to the Turkish border. While officially presented as a manoeuvre against the Islamic State, the actual motivation might have been to get there before the Kurdish-led Syrian Democratic Forces (SDF) acquired yet another territory close to the Turkish border. For Ankara, Kurdish irredentism and autonomy deliberations have been a spectre to be restrained throughout the history of the Turkish Republic. Having seen the Syrian Kurds benefit from the Syrian civil war and even gaining international support from the United States and Russia, the prospect of a de facto Kurdish autonomous region along the Turkish border has become a real concern for Turkey.

Certainly, it is not the first time Turkey and Syria have been at odds over the "Kurdish Question"2 . In October 1998, Turkey and Syria were on the brink of war, following an intensification of clashes and casualties between Turkish forces and the Kurdistan Worker Party (PKK). Turkey accused Syria of providing a safe haven for the PKK and its leader Öcalan, yet military intervention was avoided as Turkey and Syria agreed to sign the Adana Agreementii . This accord established de facto cooperation between Damascus and Ankara against the militant Kurdish forces as well as furthering efforts for greater Turkish-Syrian cooperation. While this anecdote illustrates that the cross-border character of the "Kurdish Question" has at times been a flashpoint or anchor for cooperation between Ankara and Damascus, it does not explain why Turkey chose to intervene in Syria five years after the beginning of the Syrian conflict. This policy brief analyses the current Turkish engagement in Syria in an attempt to shed light on the multifaceted motivations driving Turkey's foreign policy in late 2016. 


\section{Zero problems?}

Since the AKP took office in 2002, Ankara has pursued a foreign policy vision of "zero problems with neighbours". Invoked by former foreign and Prime Minister Davutoğlu, Turkey believed in an historical responsibility to forge ties and expand its influence over the states of the former Ottoman Empire.iii Apart from historical bonds, Islam as a shared religion should be the means to form cordial relations with Turkey's Middle Eastern neighbours. When the Arab uprisings started in 2011, Ankara was quick to promote the democratic protests - and some even looked to Turkey as a model for a successful symbiosis between Islam and democracy. In Syria, Turkey's foreign policy elite was eager to shape the uprising from the beginning. Syria had become the 'poster boy'iv of Turkish foreign policy, including high-level cooperation and economic integration. However, as the Syrian revolution dissolved into a volatile civil war, the conflict environment meant that this policy increasingly backfired, complicating and even jeopardising Turkish national interests.

It is a story of different political strategies and unpredictable turnarounds, ranging from political dialogue with the Al-Asad regime in early 2011 to an outright military escalation with "boots on the ground" in Syria in late 2016. Turkey had to realise that Al-Asad would not yield power, regardless of relentless Turkish diplomatic efforts. Regime-change in Syria became the top priority of the AKP-leadership, precluding any possibility of negotiation with the Syrian leadership. However, breaking with Damascus did not mean a solution to the Syrian crisis. International diplomacy was blocked - the international community was increasingly split into a pro- and contra-Al-Asad camp. A game-changer was Russia's intervention in 2015, re-tuning the balance against the Turkish-backed opposition groups. In late 2015, Turkey did not have an ambassador in Syria, Israel or Egypt, it recalled its envoys from Moscow and Bagdad and increasingly differed with the United States on the question of who to support in the Syrian quagmire. Add to this the increasing tensions with the EU and differences over the Kurdish Question and Turkey found itself quite isolated in the region it had tried to shape. While policy makers initially spoke of a "precious loneliness'v that would pay off in a matter of months, there was a gradual realisation that a re-calibration of foreign policy was needed. 
The major question that of course arises is whether Turkish foreign policy in Syria will change following the attempted coup d'état last July. Turkey bemoaned the fact that none of its traditional allies had positioned itself with Ankara in the immediate aftermath of the coup. Instead, Russia was one of the first countries to stand by Turkey. To infer from this that Turkey would now cherish deeper relations with Russia over the West is somewhat far-fetched. However, one can witness a re-configuration of Ankara's Syria policy, culminating in the military intervention in late August. But let us examine this process in more detail.

The actual re-calibration of Turkish foreign policy already started in June 2016, one month before the coup d'état. New Prime Minister Yildirim announced Turkey's priority as "to increase its friends, and decrease its enemies" - ironically a phrase in line with his predecessor Davutoğlu and the policy of zero problems. ${ }^{\text {vi }}$ One of the first signs of this new approach was a 'normalisation' of relations with Israel, Egypt and Russia. Crucially, Erdoğan sent a letter to Putin apologising for the shooting of the Russian fighter jet(s) in late November 2015 - the controversy which had stirred the deterioration of Russian-Turkish relations over the previous months. Underlining the high costs of non-cooperation, particularly in economic terms, Moscow and Ankara rekindled their relationship. Not without benefitting Russian interests of course, as some observers saw this as a strategic move to pull Turkey further away from its traditional Western allies. In any case, reinvigorated relations with Russia coincided with the acceptance that peace in Syria does not necessarily require regime-change in Damascus. vii

\section{A new calculus: down with the Kurds}

Regardless of whether the ousting of Davutoğlu was actually important for triggering a new foreign policy orientation, it is fair to say that Turkey has become more 'pragmatic instead of idealistic'viii. Arguably, the "calculus has shifted" and the new AKP discourse is no longer oriented against the devil Syrian regime but against Kurdish expansionism in Syria. ${ }^{i x}$ The spectre of an autonomous Kurdish entity along the Turkish-Syrian border is a major driver of Turkey's Syria policy - particularly because it is directly linked to Turkey's domestic Kurdish concerns. 
Briefly put, the Syrian Kurds made a sort of non-aggression pact with the Al-Asad-regime in July 2012. In return for withdrawing regime troops from Northern Syria, the Kurds were granted a de facto authority over these regions ${ }^{\mathrm{x}}$. Effectively, the Democratic Union Party $\left(\mathrm{PYD}^{3}\right)$ and its armed counterpart, the Popular Defense Committees (YPG) quickly gained the upper hand as the most dominant Kurdish forces in Syria. ${ }^{x i}$ In November 2013, they proclaimed the self-declared autonomous region of Rojava. In the beginning, Ankara did not really fear the Syrian Kurds as Rojava's three cantons Efrin, Kobani and Jazira were non-contingent enclaves along the Syrian-Turkish border. Since 2014, things have changed, however. The 2014 battle of Kobani between the Kurdish forces and the Islamic State exposed Turkey's ambivalent position. Turkish soldiers were literally sitting and watching from their tanks on Turkey's side of the border as severe clashes between Kurds and Islamists happened a few metres further on Syrian territory.

Of course this intensified tensions and mutual suspicions between Ankara and both Syrian and Turkish Kurds, who bemoaned that Turkey would indirectly support ISIS to curb Kurdish expansionism in Syria. ${ }^{\text {xii }}$ Ankara stayed mostly silent and waited while the US-led international coalition conducted air strikes in Kobani. AKP officials stressed that their hands were bound because at the same time ISIS held 50 Turkish hostages in Mossul. However, at no point did Ankara deny its reluctance to come to the aid of the Kurdish forces who they equated with adherents to the PKK. ${ }^{\text {xiii }}$ It is from this point onward that Ankara prioritised its national (security) interests over the larger vision of finding a solution to the Syrian conflict.

For the Syrian Kurds, preserving Kobani from ISIS was a great success. Not only could they maintain their authority over the majority-Kurdish Syrian regions, more significantly the YPG gained international credit as the most effective force in the fight against ISIS. With international support, the PYD managed to capture the border town of Tal Abyad in summer 2015. In so doing, they effectively linked the autonomous cantons of Kobani and Jazira, creating a vast Kurdish-dominated region along the border. ${ }^{\text {xiv }}$

Why is Kurdish expansionism considered a greater threat by Turkey than the Islamic State? Turkey saw ISIS as a "recent and potentially temporary threat" ${ }^{\prime \prime}$ particularly as long as the Islamic State did not pose a direct threat to Turkish national security. Things were different with the PKK, however. In the eyes of the Kurdish militants, ISIS' July 2015 bomb 
attack in Suruc, killing mainly pro-Kurdish activists, was the final evidence that the AKP government tolerated the Islamic State in those Turkish areas dominated by the Kurds. Subsequently, the PKK resumed its policy of violence, committing a series of terrorist attacks against the Turkish state and civilians as of summer 2015. Simultaneously, Ankara's fear of an autonomous Kurdish region along the southern border with Syria was tangible, owing to both Turkey's traditional objection to Kurdish independence and the fear that giving assistance to the PYD might translate into assisting the PKK. Taken to its extreme, AKP elites feared that "the success of their brethren might embolden Turkish Kurds to seek greater autonomy, and could engender the formation of a united Kurdish front that encompasses southeastern Turkey, western Iraq and northern Syria". xvi

\section{In 2016, things are still different...}

Turkey in 2016 is certainly a different country to how it was only a few months ago. Three major developments have had an impact on the current state of Turkey's Syria policy. First, the Islamic State has attacked Turkish territory in a series of attacks during the last twelve months. This has sharpened the perception of being under threat on the part of Turkish officials, who had hitherto underestimated the threat posed by Turkey's relatively lax border polic ${ }^{x v i i}$. Second, the Kurdish peace process was a failure last year, leading to a renewed downward spiral of violence and civil-warlike clashes in south- eastern Turkey. Third, the recent coup d'état was a major blowback to the stability of both state and military institutions in Turkey. The continuous purges affect Turkey's capacity to act, including in its foreign relations. How does all this play out on the ground in Syria? A good case in point is the recent Euphrates Shield mission, launched in late August 2016 by the Turkish military.

\section{Euphrates Shield-lessons learned from Jarablus}

With Tal Abyad gone, the Islamic State's only remaining direct access point to the Turkish border was Jarablus, a city on the banks of the Euphrates. Jarablus served as the Islamic State's main "smug- gling and trade hub in northern Syria". xviii From the Kurdish perspective, capturing Jarablus would be a symbolic step towards establishing a connection with 
the last remaining enclave of Efrin in the North- west. Aware of this, Turkey got nervous when Kurd- ish-led forces crossed the Euphrates westward in May 2016 as part of the Manbij operation, a US-sup- ported Kurdish mission to re-capture the city of Manbij from IS forces.

The recent developments are illustrative of a wider schism in the USTurkish relationship, as the Ameri- cans continue to rely on Kurdish SDF forces instead of Turkish-backed Arab rebel forces. The Americans fear being dragged into a confrontation with Al-Asad groups while Turkey does not want any cooperation with a group they deem to be 'terrorists'. ${ }^{x i x}$ Eventually, the United States had to show some understanding for Turkey's attitude as a NATO ally. Likewise, the Kurds needed to comply with calls to move behind Euphrates borders to maintain US military support. Vice-President Biden visited Turkey and urged the Kurds that they "cannot, will not, and under no circumstances will get American support if they do not keep their commitment". ${ }^{\mathrm{x}}$ In the face of mounting domestic pressures and the growing Kurdish insurgency at home, Turkey decided to send its own troops, effectively constituting the first foreign force in Syria to deploy "troops on the ground". The Turkish forces aimed to assist Turkish-backed FSA forces in their fight against ISIS, and following the successful capture of Jarablus from the extremists, government advisor Kalin claimed: "the myth that the YPG is the only effective force fighting against DAESH has completely collapsed", thereby indirectly criticising US support for the Kurds. ${ }^{\mathrm{xxi}}$

Officially, the AKP's goal was to ensure "border security and Syria's territorial integrity while supporting the international US-led coalition against the Islamic state". xxii Cooperation with the US was thus a key pillar of the Euphrates Shield mission, yet as several observers note, this was based on a mutual agreement: in exchange for cooperation in fighting the Islamic State, the US would grant the "Euphrates red line", implying keeping the Kurdish forces east of the river. Thus, while the official mandate was to fight back ISIS, one can equally infer that Turkey performed a pre-emptive strike before the Kurds reached Jarablus. AKP advisor Ibrahim Kalin's statements are very straightforward in this regard: "the Democratic Union Party (PYD) and its armed wing, the YPG, are seeking to move into areas fled by DAESH and create conditions on the ground to grab more land. Turkey defends Syria's territorial integrity against the PKK propaganda and its supporters in the West and will not allow a PKKled statelet along its border".xxiii 
This discourse reveals the general tendency of the AKP discourse since the failed Kurdish peace process in 2015: renowned Turkish journalist Mustafa Arkyol compares the AKP's position on the Kurds to the rightwing drift in Israel following the failed Oslo Peace Process in 2000: "We tried peace with these terrorists, the common logic in both cases read, "and saw that they only understand through force."xxiv In any case, Turkey was aiming to be well-positioned in a potential post-ISIS environment in Syria. Allowing the Syrian Kurds a free hand in such a scenario was not part of Ankara's equation.

Where does the coup d'état come in? At first glance, one might argue that starting a military operation in another country is an absurdity following the purges of thousands of officials. Authors agree that the military has been weakened by the post-coup purges, losing effectiveness and cohesion maybe even for years to come. Mc Leary ${ }^{\mathrm{xxv}}$ accentuates that the vacuum in the higher ranks of the military is particularly alarming for both Turkey and NATO, "in a major NATO ally that is already under strain from terrorist attacks, a huge population of refugees, and a war next door in Syria". However, the decision to send troops abroad at this point could have been facilitated by the climate of post-coup reprisals: first, Turkey might have felt emboldened to act unilaterally by playing the 'Gülen Card'. Accordingly, the US would not object to Turkey's military move in the face of recent accusations about playing host to Gülen and conspiracies with regard to the coup d'état xxvi. ${ }^{4}$ Second, by sending the Turkish infantry into battle, Erdoğan could show that "he was in form command of the armed forces... and also deflect attention from the turmoil of Turkey's domestic politics". xxvii It is a paradoxical situation: The coup d'état allowed Turkey to "play a more adventurous role in the region, by giving troops a fight outside Turkey, and making those irredentist visions that much harder to achieve". xviii

\section{Conclusion: what lies ahead?}

A recent article in the Economist summarises that the Euphrates Shield mission allowed Turkish troops and their proxies to take control of an area of more than $90 \mathrm{~km}$ between Jarablus and Azaz along the Syrian border. ${ }^{x i x}$ While not really the "safe zone" Ankara had dreamed of in the beginning of the Syrian conflict, Erdoğan still managed to kill "two birds with one stone": ISIS has been hit logistically and in its capacity to con- 
duct cross-border shelling, and the Syrian Kurds did not accomplish the connection of their three cantons to form a de facto Kurdish federation on Turkey's southern border. ${ }^{\mathrm{xxx}}$

Considering the operational difficulties of an army under full re-construction, observers claiming that Turkey might now take on Raqqa next are simply neglecting realities. Strategically, the Islamic State's 'capital' in Syria is way more difficult to capture than Jarablus, Manbij or Kobani. Even to get there, Turk- ish forces would have to cross either PYD-dominated areas or make a turn by Aleppo through areas held by regime troops. ${ }^{\text {xxxi }}$ Add to this Erdoğan's fear of losing control of Turkey's domestic situation and one soon realises that the AKP discourse is probably stronger than the actual willingness for continuous military adventures in Syria (and Iraq). Therefore, one should not overestimate Erdoğan when he speaks in favour of direct intervention in Mossul or Raqqa. Instead, these "Neo-Ottoman" statements are arguably meant to "sustain a wave of nationalist frenzy on which Erdoğan seeks to ride to a new constitution and an executive presidency next year". ${ }^{x x x i i}$ For the time being, Turkey's intervention has proven its continuous regional ambitions, although in a completely different form to a few years ago. By stepping up relations with former foes such as Russia, Turkey has re-gained some of the leverage it strives for in its immediate neighbourhood. At the end of the day, however, Erdoğan's overriding goal is fortifying his domestic power, leading some to argue that the recent domestic purges are a "counter-coup"xxxiii to repress any potential opposition to his leadership. Turkey's domestic and external affairs, it cannot be emphasised enough, remain deeply entwined.

As for the future of the Syrian conflict as such, there is too much "military parity on the battlefield for anything but protracted fighting". xxxiv Sadly enough for the thousands of civilians who have been victims of the war, the latter has turned into a chess board dominated by the regional and international actors. The actual prize is not necessarily winning the war; instead all parties involved are attempting to get the best deal/influence out of the complex situation. "As factions jostle for influence, the original causes of the conflict slowly fade away and opportunistic deals become the new order of the day, among the insurgents and government supporters on the ground as well as among the war's many regional actors". ${ }^{x x x v}$ While Aleppo proper is in a continuous stalemate, the wider question in Northern Syria will be to be well-positioned in a potential post-ISIS situation: "a war of positioning in the Jarablus-Manbij region has now clearly com- 
menced". xxxvi An end of the Syrian calamity, however, is not in sight and as some argue, not necessarily desired.

*Sebastian Franzkowiak is CIFE Alumnus. His major research interests are Turkish foreign policy, the Syrian conflict and the transformation of the Arab world.

1. A thank you for your opinion goes to Ayhan Kaya and Silvia Colombo.

2. Mentioned since 2005 by Erdoğan as part of his reconciliation attempt with Turkey's Kurds, the Kurdish question could equally be understood as the continuous controversy over the Kurds' statelessness, making them the largest cross-border ethnic group without a state.

3. Established in 2003 as an offshoot of the Turkish PKK, the PYD - unlike its Turkish counterpart - is not considered a terrorist network but an official party. Turkish officials do however equate the two groups as one and the same 'terrorist organisation'.

4. Turkish media - controlled up to $90 \%$ by the AKP government - claim that 'FETÖ' (Fethullah Gülen Terror Organisation) is behind the coup. The Obama administration rejected any alleged links to the coup and asked for evidence to justify Gülen's extradition to Turkey.

\section{References:}

i Coined by Plato.

ii Tocci, N. \& Aydin-Düzgit, S. (2015). Turkey and the European Union. London: Palgrave Macmillan.

iii Davutoğlu, A. (2009). Principles of Turkish of Foreign Policy. Address by H.E. Foreign Minister of Republic of Turkey Ahmet Davutoğlu. SETA foundation: Washington D.C.

iv Kan, A.K. (2013). Paradise Lost: A Neoclassical Realist Analysis of Turkish Foreign Policy and the Case of Turkish-Syrian Relations. In: Hinnebusch, R. \& Tür, Ö. (2013). Turkey-Syria Relations: Between Enmity and Amity. Ashgate: Ashgate Publishers.

v Kalin, I. (2014). What Turkey Wants in the War on ISIS. Why are we alone being asked to commit troops? Why isn't removing Assad part of the plan? Washington Post Online Journal. Retrieved April 14, 2016, from http://www.wsj.com/articles/ibrahim-kalin-whatturkey-wants-in-the-war-on-isis-1413758083

vi Van Wilgenburg, W. (2016). Turkish foreign policy after the military coup.International Policy Digest - The Foreign Policy Associa- 
tion. Retrieved October 22, 2016, from http://intpolicydigest.org/ 2016/08/17/turkish-foreign-policy-military-coup/

vii Aydintasbas, A. (2016). The amazing speed of Turkey's foreign policy U-turn. European Council on foreign relations. Retrieved October 15, 2016, from http://www.ecfr.eu/article/commentary_the_amazing_speed_of_turkeys_foreign_policy_u_turn_7070 viii Özer, V. (2016). Carnegie Policy Brief. Will Turkey change its Syria policy? Four experts answer. Retrieved October 14, 2016, from http://carnegie-mec.org/diwan/63865

ix Ülgen, S. (2016). Carnegie Policy Brief. Will Turkey change its Syria policy? Four experts answer. Retrieved October 14, 2016, from http://carnegie-mec.org/diwan/63865

x Park, B. (2015). Turkey's isolated stance: an ally no more, or just the usual turbulence? International Affairs, 91 (3), 581-600.

xi Hevian, R. (2013). The main Kurdish political parties in Iran, Iraq, Syria, and Turkey: A research guide. Middle East Review of International Affairs, 17 (2), 94-104

xii Barkey, H. (2014). Turkey's Syria predicament. Survival: Global Politics and Strategy, 56 (6), 113-134.

xiii Tocci, N. (2014). Turkey, Europe and the Syrian Crisis: What Went Wrong? In: Aydin-Düzgit et al. (2014). Global Turkey in Europe II: Energy, Migration, Civil Society and Citizenship Issues in TurkeyEU Relations. IAI Research Papers, 2014, 139-145.

xiv Kasapoglu et al. (2015). A Turkish Intervention in Syria: A reality check. Edam Discussion Paper Series 2015/2.

xv Ibid.

xvi Ekim, S. (2015). Turkish Boots Will Remain on Turkish Ground.

Why is Turkey Reluctant to "Do What it Takes" at Kobane? In: Aydin-Düzgit et al. (2014). Global Turkey in Europe III. Democracy, Trade, and the Kurdish Question in Turkey-EU Relations, 59-65. xvii Kasapoglu et al. (2015). A Turkish Intervention in Syria: A reality check. Edam Discussion Paper Series 2015/2.

xviii Lund, A. (2016). After murky diplomacy, Turkey intervenes in Syria. Syria in Crisis - Diwan: Carnegie Middle East Center. Retrieved November 3, 2016, from http://carnegie-mec.org/diwan/64398 xix Itani, F. (2016): Why Turkey went to war in Syria. Retrieved November 2, 2016, from http://foreignpolicy.com/2016/08/24/whyturkey-finallywent-to-war-in-syria-jarablus-invasion-kurds/ 
xx De Young, K. (2016). Biden warns Kurds not to seek separate enclave on Turkish-Syrian border. The Washington Post. Retrieved October 14, 2016, from https://www.washingtonpost.com/world/ biden-visits-turkey-on-mission-to-repair-strained-relations/ 2016/08/24/bc684904-6a04-11e6-99bf-f0cf3a6449a6_story.html

xxi Kalin, I. (2016). Turkey's resilience after the coup. Retrieved October 22, 2016, from http://www.dailysabah.com/columns/ibrahimkalin/2016/08/30/turkeys-resilience-after-the-coup

xxii Lund, A. (2016). After murky diplomacy, Turkey intervenes in Syria. Syria in Crisis - Diwan: Carnegie Middle East Center. Retrieved November 3, 2016, from http://carnegie-mec.org/diwan/64398

xxiii Kalin, I. (2016). Turkey's resilience after the coup. Retrieved October 22, 2016, from http://www.dailysabah.com/columns/ibrahimkalin/2016/08/30/turkeys-resilience-after-the-coup

xxiv Akyol, M. (2016). How Turkey's AKP undid its legacy on 'Kurdish question'. Retrieved October 24, 2016, from http://www.al-monitor.com/pulse/originals/2016/10/turkey-kurds-jailed-mayors-akpundid-legacy.html

xxv Mc Leary, P. (2016). Turkey's Ongoing Military Purge drives, complicates regional ambitions. Foreign Policy, October 2016. Retrieved November 1, 2016, from http://foreignpolicy.com/ 2016/10/27/turkey-ongoing-military-purgedrives-erdogan-regionalambitions-mosul/

xxvi Baydar, Y. (2016). How the failed putsch in Turkey evolved into a counter-coup. Südosteuropa Mitteilungen, 04/2016, $5 \mathrm{ff}$.

xxvii Sayigh, Y. (2016). Smoke and mirrors. Diwan - Carnegie Middle East Center. Retrieved November 5, 2016, from http://carnegie-mec .org/diwan/64889

xxviii Mc Leary, P. (2016). Turkey's Ongoing Military Purge drives, complicates regional ambitions. Foreign Policy, October 2016. Retrieved November 1, 2016, from http:/foreignpolicy.com/ 2016/10/27/turkey-ongoing-military-purgedrives-erdogan-regionalambitions -mosul/

xxix Erdogan's War Game. The Economist, web-edition. Retrieved November 3, 2016, from http://www.economist.com/news/middleeast-and-africa/21709338-turkish-president-pushing-both -his -southern-neighbours-erdoganswar

xxx Ibid 
xxxi Itani \& Stein (2016). Turkey's Syria predicament. The Atlantic Council. Retrieved October 27, 2016, from http://www.atlanticcouncil.org/publications/issue-briefs/turkey-s-syria-predicament

xxxii Erdogan's War Game. The Economist, web-edition. Retrieved November 3, 2016, from http://www.economist.com/news/middleeast-and-africa/21709338-turkish-president-pushing-both-hissouthern-neighbours-erdoganswar

xxxiii Baydar, Y. (2016). How the failed putsch in Turkey evolved into a counter-coup. Südosteuropa Mitteilungen, 04/2016, 6ff.

xxxiv O'Hanlon, Michael E. (2016). A Syrian deadlock for years to come. Brookings, Order from Chaos. Retrieved on November 4, 2016, from https:/www.brookings.edu/blog/order-from-chaos/ 2016/10/17/a-syrian-deadlock-foryears-to-come/

xxxv Lund, A. (2016). After murky diplomacy, Turkey intervenes in Syria. Syria in Crisis - Diwan: Carnegie Middle East Center. Retrieved November 3, 2016, from http://carnegie-mec.org/diwan/64398 xxxvi Ibid. 